University of Nebraska - Lincoln

DigitalCommons@University of Nebraska - Lincoln

Space, Cyber, and Telecommunications Law

Program Faculty Publications

Law, College of

2006

\title{
Space for Tourism? Legal Aspects of Private Spaceflight for Tourist Purposes
}

Frans G. von der Dunk

University of Nebraska - Lincoln, fvonderdunk2@unl.edu

Follow this and additional works at: https://digitalcommons.unl.edu/spacelaw

Part of the Air and Space Law Commons

von der Dunk, Frans G., "Space for Tourism? Legal Aspects of Private Spaceflight for Tourist Purposes" (2006). Space, Cyber, and Telecommunications Law Program Faculty Publications. 26.

https://digitalcommons.unl.edu/spacelaw/26

This Article is brought to you for free and open access by the Law, College of at DigitalCommons@University of Nebraska - Lincoln. It has been accepted for inclusion in Space, Cyber, and Telecommunications Law Program Faculty Publications by an authorized administrator of DigitalCommons@University of Nebraska - Lincoln. 


\section{SPACE FOR TOURISM?}

Legal Aspects of Private Spaceflight for Tourist Purposes

Frans G. von der Dunk

International Institute of Air and Space Law, Leiden - The Netherlands

F.G.vonderDunk@law.leidenuniv.nl

\begin{abstract}
$\underline{\text { Abstract }}$
It is barely five years ago since the first space tourist proper, Mr. Dennis Tito, made his much-publicised 20 milliondollar flight to the ISS. And now, purportedly thousands of prospective customers are lining up with such nascent companies as Sir Richard Branson's Virgin Galactic, for a 200,000-dollar, few-minute flight into the nearest part of outer space. In other words: it looks like space tourism is here to stay.

This obviously raises a number of key legal issues, stretching from proper application of such international space treaties as the Liability and Registration Conventions to national legal issues pertaining to liabilities, licensing and certification, and civil and criminal jurisdiction and control.

The present paper seeks to offer an overview of some of these, the most salient legal issues as they are on the table right now, keeping in mind the need to maintain a fair balance between the interests of private enterprise and of the public at large - nationally as well as internationally - respectively.
\end{abstract}

\section{$\underline{1 . \text { Introduction }}$}

Over the span of just a handful of years, space tourism (for the moment to be defined as "flights into outer space of humans for their own pleasure and excitement") has been transformed from a notion being little more than science fiction to an impending commercial business. If the flight of Mr. Tito in 2001 could still be considered an exotic multi-millionaire's stunt, already three years later the Xprize changed such perceptions dramatically. Twice within a few weeks in that October of 2004 did a privatelyfinanced craft, using relatively simple but rather revolutionary technology, reach an altitude of over $100 \mathrm{~km}$, the unofficial boundary of outer space. The technology has immediately been picked up by Virgin Galactic, which about half a year ago already had some 43,000 bookings and down-payments to the tune of 13 million US\$ for trips to be offered as of 2008 . $^{1}$

While the US government has reacted by enunciating a specific Act to deal with this latest development, ${ }^{2}$ this Act was only a temporary one. ${ }^{3}$ Moreover, it is clear that space tourism will also generate substantial legal issues beyond the borders and jurisdiction of the United States - already in the case of Virgin Galactic it should be noted that this concerns a UK company.

The present paper offers a summary overview of some of the most salient legal issues as they play out both at an international and at a national level.

\section{International level}

\subsection{Introductory remark}

Starting at the international level - as should be the case, bearing in mind the fundamentally international character

Copyright@2006 by Frans G. von der Dunk. Published by the American Institute of Aeronautics and Astronautics, Inc., with permission. 
of outer space as an area ${ }^{4}-$ it is immediate obvious that spaceflights for pure pleasure purposes were never as such envisaged by the drafters of the key space treaties.

\subsection{The Outer Space Treaty}

The Outer Space Treaty was essentially focused on two reasons for conducting any, including manned, spaceflight: military/political ones (where it tried to minimise the risks of space becoming a battleground) and scientific ones (where it tried to establish and protect the freedom to investigate, explore and even use outer space). ${ }^{5}$ With a view to space tourism, the major conclusion too be drawn from the Outer Space Treaty therefore is: as long as no specific rules prohibit or condition (certain forms of) space tourism, the freedom of use of outer space as point of departure allows space tourism as part of such use, even if nowhere specifically mentioned.

The only more directly relevant reference to the current issue is offered by Article V, which had been drafted to ensure that astronauts (and cosmonauts and taikonauts) would be treated in conformity with certain standards - as mainly expressed by the concept of "envoys of mankind". That concept had never been defined any further, although it was generally considered not to equate in law with an 'envoy' in the terrestrial, diplomatic sense of the word. Formally, no diplomatic immunities were offered to an astronaut stranded in a foreign country. Under Article V, the duties of the 'receiving state' had been 'limited' to assistance as well as prompt and safe return to his 'sending' state; they did not provide for any formal entitlement of the astronaut to immunity from jurisdiction. To be sure, the astronaut's presence within a foreign jurisdiction was essentially of an emergency and - as a consequence supposedly rather temporary character.
In view of that fact of life, it was simply not very likely the astronaut would even get the chance to undertake any deliberate action in violation of domestic laws potentially triggering the receiving state's jurisdiction and, thus, the question of any immunities.

The relevant provisions were, of course, drafted keeping in mind humans going into space as 'professionals', that is trained and paid by their respective governments (or exceptionally by an intergovernmental organisation, read ESA) to go into outer space. Hence, it was precisely the fundamental nonprofessional nature of space tourists which raised the issue in many minds of whether they should be considered astronauts and hence enjoy the status of the relevant provisions.

The 'follow-up' treaties to the Outer Space Treaty equally proceeded on that basis, although in view of the more explicit and concrete character of most of their articles the question whether individual articles would impose relevant conditions on space tourist activities became much more acute.

\subsection{The Rescue Agreement}

This firstly concerned the Rescue Agreement ${ }^{6}$, which elaborated Article $\mathrm{V}$ of the Outer Space Treaty. The Rescue Agreement followed the latter's exclusive focus on professional astronauts and even seemed to elaborate it, by referring throughout to "personnel of a spacecraft" as enjoying the rights of being assisted and safely and promptly returned as spelled out by the Agreement. ${ }^{7}$ Not entering into the discussion here of the extent to which the "personnel of a spacecraft" of the Rescue Agreement would equate with the "astronauts" of Article V of the Outer Space Treaty, it remains obvious that as such space tourists would seem to fall outside of that category. 
Apparently, there is considerable hesitation to accept this conclusion outright, as it may seem to deny space tourists the benefits of Articles 1 through 4 in particular of the Rescue Agreement, and efforts are made to stretch the concepts of 'personnel of a spacecraft' and 'astronaut' so as to include, after all, any human being in outer space including space tourists. This would be a fallacy, however, inasmuch as general humanitarian duties to assist human beings in distress do not depend on those Articles; they derive - apart from moral and ethical considerations - from customary and in many cases also codified general international law. It is not necessary for those general humanitarian purposes to interpret these Articles as extending to space tourists as well.

On the contrary, should space tourists be allowed to enjoy in particular the rights to safe and prompt return provided for by Article 4 without any caveat as to the possibility of those tourists somehow infringing national laws? That would seem to be a proposition which many, in particular non-space-faring, states would not particularly agree with - but at any rate, sufficient doubts may be cast on the validity of the claim that space tourists should enjoy the same international legal protection as personnel or astronauts under the current treaties without further ado, to warrant an effort to somehow clarify the matter on the international plane.

With regard to the flight crew, however, things would seem to lie less clear. Both their reasons for going into outer space (professional and being paid to do a job) and the types of their activities there (guiding the vehicle safely in and out of outer space, and in the case of orbital tourism, even guiding it around in outer space) are much closer to those of the 500 or so human beings that have so far entered into outer space. The only major difference, certainly from a legal perspective, is that the latter are in the service of governments or an intergovernmental organisation, the former in the service of private commercial companies.

In this case, therefore, it would make sense to equate space tourist vehicle crew, certainly the flight deck crew but possibly also any service e crew on board, to "personnel of a spacecraft", hence endowing them with the rights enunciated by the Rescue Agreement.

\subsection{The Liability Convention}

Another example of outer space treatylaw potentially relevant for the present situation would concern the Liability Convention, ${ }^{8}$ since the obvious risk exists that through the doings of a space tourist damage falling within its scope might result. As a matter of fact, however, for the Liability Convention itself it does not make any distinction whether the ultimate cause of damage would be a tourist or not - the state or states qualifying under the well-known criteria as "launching State" of the object which caused the damage will be liable. ${ }^{9}$

As a consequence, just like with respect to any other private space activity for which a particular state may be held liable on the international level, that state simply has to ensure that the relevant tourist activity is subjected to its jurisdiction and a license including proper arrangements regarding third party liabilities and insurance therefor. In other words: it becomes a matter of national (space) law and any applicable licensing system part thereof.

The only issue on which space tourism, even if de facto and for the time being, might be special concerns sub-orbital tourism and the craft used therefore. As is well-known, the application of the 
Liability Convention's regime hinges on the damage being caused by a 'space object'. ${ }^{10}$ While a space object has not been defined any further by the treaties, it is generally perceived as something which was at least intended to be launched into outer space.

As has been discussed abundantly elsewhere, there is no clear legal delimitation of outer space as of yet. This fact opens the door to a discussion as to whether flights going up vertically to an altitude of at most $120 \mathrm{~km}$ - as Virgin Galactic is currently planning to do with its SpaceShipTwo vehicles being built - and then immediately returning would qualify SpaceShipTwo craft as space objects so as to trigger the application of the Liability Convention in case of damage. As will be seen, this actually transposes the issue to the level of national law.

\subsection{The Registration Convention}

Similar considerations as regards the Liability Convention apply to Article VIII of the Outer Space Treaty and the Registration Convention ${ }^{11}$ as its elaboration, since the definition of a 'space object' through the determination of the 'launching State' underlies any retention of jurisdiction by the state of registry over that space object and its personnel while in outer space. In other words: if a craft carrying space tourists (or anything else for that matter) into the outer edge of outer space and back would qualify as a 'space object', jurisdiction of the state of registry could be applied through the workings of Article VIII of the Outer Space Treaty and Article II(2) of the Registration Convention.

The difference is not really relevant, however, as otherwise basically the same amount of jurisdiction could be exercised under air law over the craft if it would be defined as an aircraft, ${ }^{12}$ or even in the absence of such registration the craft at issue would be subject to the jurisdiction of the state that could have registered it - and might prefer other legal instruments to make the exercise of any jurisdiction effective.

It is furthermore with respect to such space objects - again not defined any further by the Convention itself - that the duty of the state of registry arises under the Registration Convention to establish a national registry and then inform the United Nations SecretaryGeneral, read the Office for Outer Space Affairs about such registered space object on at least a handful of parameters offered by the Convention. ${ }^{13}$

\section{National law issues}

\subsection{Introductory remarks}

As is the case on many other issues where international space law is not sufficiently elaborated, as soon as a practical need arises for certain states to deal in legal terms with an issue, attention automatically should be directed towards national legal actions and developments - and space tourism, obviously is no exception.

As has been discussed in many instances elsewhere, the fundamental basis for the role of national law and jurisdiction vis-à-vis space activities fundamentally derives from three parameters at the international level, which warrant being briefly reiterated here.

Firstly, there is the international responsibility of a state under Article VI of the Outer Space Treaty for "national activities in outer space", and the related obligation to exercise "authorization and continuing supervision" over private entities involved therein. Secondly, the international liability for damage by space objects also if ultimately caused 
by private actors, which results for (launching) states as a consequence of Article VII of the Outer Space Treaty and the whole of the Liability Convention, represents at least a strong stimulus for those states to try and exercise jurisdiction over those actors, in order inter alia to deal with reimbursement and insurance. And thirdly, Article VIII of the Outer Space Treaty as further elaborated by the Registration Convention, as mentioned, offers to states a specific, spaceoriented tool to exercise some measure of jurisdiction over a space object - for example for any of the above reasons as a consequence of registering the space object in question.

In addition, however, to these major international legal parameters for national legislative action, national law, once it starts to deal with space tourism, also inserts some further parameters in this case largely stemming from the experience in aviation.

From this perspective, it may be concluded that three major issues need to be dealt with: the craft, the crew, and the passengers.

As for the craft, the above discussion already to some extent indicates the need under international law to determine whether the craft used for space tourism - certainly as long as suborbital and of the SpaceShipTwomode - constitutes an aircraft or a space object, or possibly even both. This issue in addition however also has some distinct national law-aspects, as will be seen.

As for the crew and the passengers, in respect of both the international aspects have also been addressed above. Here, national laws play an even more important role than on the issue of the craft, and from the experience of aviation, it is clear that the distinction between crew and craft is much more perfected.

\subsection{The United States}

In the absence of any authoritative guidance on the international level, the United States, as the one country so far actually having had to deal with space tourism, by means of the Commercial Space Launch Amendments Act of 2004 had to deal with the three issues referred to.

With regard to the craft, the US authorities decided for SpaceShipOne to consider it as an experimental aircraft, as it did with respect to its carrier aircraft White Knight. ${ }^{14}$ By contrast, SpaceShipTwo, it is the US authorities' intention, will be registered as a spacecraft, even as the carrier is a more or less normal aircraft and SpaceShipTwo, like SpaceShipOne, in its return phase will operate as a glider and will be registered with the Federal Aviation Administration with a code usually reserved for aircraft. ${ }^{15}$ It remains to be seen, of course, to what extent this precedent will be followed by other examples, read other countries, with a view to the possible formation of a rule of customary law, but it is obvious that this US example would tend to be followed unless solid reasons would tell against that.

At the national level, however, the issue of the craft has another, more down-toearth aspects as well: that of certification. Though even in aviation there is little harmonisation as to the contents and detailed procedures for certification of craft - basically, all is left to national authorities in that context - at least the principle of certification is well established at the international level, leading to an enormous amount of certification regulation and activity at the national level. ${ }^{16}$ And, it should be added, in Europe also at the regional international level, in the context of the Joint Aviation Authorities (JAA) ${ }^{17}$ and the 
newly established European Aviation Safety Agency (EASA) ${ }^{18}$.

In this respect it is noteworthy that, purportedly without any obligation to do so, Virgin Galactic with regard to its SpaceShipTwo craft is looking for Part 25 certification for aircraft in the United States, without however intending to go through all the testing normally required for that purpose. ${ }^{19}$

The Commercial Space Launch Amendments Act itself remains silent on the issue, but it is likely that in the process of updating and amending or replacing it this issue will be taken on board prominently.

When it comes to the issue of the crew, the Act is quite specific and defines it as "any employee of a licensee or transferee, or of a contractor or subcontractor of a licensee or transferee, who performs activities in the course of that employment directly relating to the launch, reentry, or other operation of or in a launch vehicle or reentry vehicle that carries human beings". ${ }^{20}$ The tourists themselves are clearly distinguished therefrom, as anyone on board not being a member of the crew, by means of the term "space flight participants". ${ }^{21}$

As to the latter, Mr. Whitehorn, CEO of Virgin Galactic, at his keynote speech addressing the ECSL Practitioners' Forum in Paris on March 17, 2006, stated that "individual medical risks [of passengers] now would constitute the highest ones, not those of equipment or vehicle failure". ${ }^{22}$ Hence, Virgin Galactic was developing a policy for its SpaceShipTwo operations which would fundamentally exclude only passengers with cardiac or coronary weaknesses, as well as those under sixteen years of age.

This might still raise some issues regarding potential (passenger) liability, which may ultimately lead to the establishment of a national regime on passenger liability or even an international convention trying to harmonise such national regimes along the lines of the Warsaw system in air transport. ${ }^{23}$

For the time being, this problem has been pushed forward in that, for operations of this nature under the Commercial Space Launch Amendments Act, the obligation to clearly inform passengers of the dangers inherent in a relevant flight was the sole relevant requirement on this issue for obtaining a license under the Act, effectively excluding him from claiming any liability as a third party. ${ }^{24}$ This would leave intact, barring further provisions to the contrary, the application of the existing US regime for dealing with third party liability including international claims under the Liability Convention. This regime, essentially operating through a licensing process, is well-known.

In short, it amounts to a licensing obligation for launches conducted from US territory and/or by US persons or legal entities abroad, and under circumstances also by non-US companies if a controlling interest would be in US hands. ${ }^{25}$ Included in any license then is the obligation for the licensee to either insure himself or show "financial responsibility" up to an amount which is the lowest of the three following: (1) the maximum probable loss as calculated by the licensing authority; (2) the maximum liability insurance available on the world market at reasonable cost as determined by the licensing authority; and (3) the amount of US \$ $500,000,000 .^{26}$

\subsection{The United Kingdom}

As briefly discussed, so far only the United States has, to any appreciable extent, drafted legislation dealing with space tourism. That leaves the question 
open, to what extent other states would, if not from their own national legal perspective at least from the international legal perspective, be involved in space tourism, and whether whatever law is currently in place, would suffice for the moment to deal with it.

The first state coming to mind is obviously United Kingdom, in view of the fact that Virgin Galactic, the company closest to realizing sub-orbital tourist flights, is still a UK company, even as the technology is owned by a (presumably American) joint daughter company of Virgin Galactic and Scaled Composites, and the operations, for the time being, will be conducted from US soil, in the state of New Mexico.

Virgin Galactic flights, to the extent constituting "activities in outer space" with reference to Article VI of the Outer Space Treaty, would certainly trigger UK responsibility as a state. It could even be argued that the United Kingdom, by allowing Virgin Galactic flights to go ahead, would come to qualify as a state that "procures" the launch, the notion of 'procuring a launch' never having been authoritatively defined. This, of course, might entail liability for the United Kingdom - in this case next to the United States, qualifying as a launch state already by reason of the launch taking place from New Mexico. ${ }^{27}$

The United Kingdom has, indeed, a national space law $^{28}$ in place, which provides in this regard for a license obligation for any body "incorporated under the law of any part of the United Kingdom" if it undertakes the launch or procurement of the launch of a space object, or operates it, "whether carried on in the United Kingdom or elsewhere". ${ }^{29}$

By way of exceptions, if "arrangements have been made between the United Kingdom and another country to secure compliance with the international obligations of the United Kingdom", a license is not required, and in addition the UK Secretary of State may waive the license obligation "if he is satisfied that the requirement [of obtaining a license] is not necessary to secure compliance with the international obligations of the United Kingdom". ${ }^{30}$

Part of the license obligation finally concerns the obligation to indemnify the UK government in respect of any international liability claims which the latter had to submit to, in principle comprehensively but in practice likely limited to the amount of obligatory insurance coverage. $^{31}$

Thus, it seems, the United Kingdom at least in theory seems well equipped with the national legal means to exercise control over any space tourism operations in respect of which it may be held responsible or liable on the international level.

\subsection{United Arab Emirates \& Singapore} In regard of other states, it may be pointed out that their possible involvement in space tourist operations seems to be considerably further away, since the plans concerned are in considerably less advanced stages as compared to those of Virgin Galactic.

The plans coming closest as of yet concern those of Space Adventures, which is involved in projects leading to spaceports adapted for space tourist flights in the United Arab Emirates/Dubai and/or Singapore. Space Adventures itself being a US company, it will be subject to the aforementioned US legislation, so it is essentially the other states mentioned which warrant a brief look at this point. If, indeed, such spaceport projects will turn into successful take-off sites for space tourist flights, the mere fact that the territory of the United Arab Emirates respectively Singapore might 
be used for such launches would entail possible liability for those two state as launching state - presuming of course, in the light of the discussion above, the craft in question would qualify as a 'space object'.

Neither of these two states have any specific national space law in place as of yet, and it remains doubtful whether any existing general piece of law on, for example, the licensing of private activities, and/or reimbursement obligations vis-à-vis the government would be effective to deal with the matter.

\subsection{The Russian Federation}

Furthermore, another company Rocketplane plans to offer space trips seem to consider the option of using Russian aircraft as the lower stage carrier for the craft which is to enter into outer space. In that case, not only Russian aviation law on registration and certification of aircraft may come into play, but in view of the inherently resulting character of the carrier aircraft as the "launch vehicle" also space lawconsequences result (once more, of course, assuming that the upper stage craft could be considered a 'space object'). Such a character, namely, would qualify Russia (also) as a launching state in the context of the Liability Convention. $^{32}$

That brings into the picture the national space law which Russia has enacted over a decade ago. ${ }^{33}$ The Law of the Russian Federation on Space Activities provides for a licensing obligation for all "organizations and citizens of the Russian Federation or (...) foreign organizations and citizens under the [territorial] jurisdiction of the Russian Federation". 34 This licensing obligation ratione materiae applies to space activities, including "preparation for launching and launching of space objects, as well as control over space flights". 35

In other words: a non-Russian company like Rocketplane does not as such fall within the licensing obligation provided for by the Law of the Russian Federation on Space Activities, even though such launches may entail liability of Russia under the prevailing international liability regime.

The way out here for Russia may be provided by another clause in the Law of the Russian Federation on Space Activities, which deals with registration: Article 17(2) namely explicitly provides that the jurisdiction of Russia applies also to Russianregistered space objects. This, of course, presumes a choice on the part of the Russian government to consider an aircraft carrier for an upper stage space tourist vehicle to be the launch vehicle of a space object in the sense of the Liability Convention - in order to cater for any potential liability claims at the international level: the circle is completed here...

Moreover, it certainly requires a Russian law somehow obliging Russian aircraft used for the purpose of launching space objects, by whomsoever wherever, to be registered as such. In sum, in this case it could be deemed rather doubtful whether the Russian authorities have the proper legal tools at hand to deal with the matter.

Once the licensing obligation is made to apply, however, the Law of the Russian Federation on Space Activities does provide for a reimbursement obligation of the licensee in case of international third party damage claims to be honored by the Russian government, as well as for the likelihood that such obligation would be without limit. $^{36}$ Furthermore, insurance against such an event for the licensee is mandatory, although the 
maximum amount of obligatory cover is to be determined by future legislation, which very likely therefore will mean such an amount will be limited. ${ }^{37}$

\section{$\underline{4 . \text { Concluding remarks }}$}

It is clear that within the scope of the present paper it has not been possible even summarily to deal with all important legal issues - which in itself testifies that space tourism is a rather interesting new phenomenon in space law if it is, indeed, to stay. This in turn raised the overarching question: is (there) space for tourism also in a legal sense?

The current, summary overview seems to answer this question largely in the affirmative: space tourism certainly is not prohibited by any of the relevant treaties, at least as long as the specific relevant rules and obligations contained therein are complied with.

Here, however, the first major issues arise. On a number of counts, too little clarity exists as to the precise impact of international space law on this new phenomenon. In turn, this gives rise to the fact of life that those states which find themselves confronted with relevant space tourist activities will of necessity find their own particular way in dealing with, for example, certification of craft or liability of operators. In addition, specific national idiosyncrasies may also creep in.

This is not to say that there is, necessarily, a need right now for any international convention - history has shown, that such efforts are too often ill-fated and/or extraordinarily slow if there is no general consensus on their desirability or need. For the time being, moreover, it will be most interesting to closely follow national US law developments, since the United States at this moment is the only state more or less immediately confronted with space tourist operations.

Yet, if we accept the fundamental premise that space tourism can contribute to the overall benefits mankind would draw from space and space activities (for instance by making access to space much cheaper and safer) these are important issues for further analysis in the forthcoming years - and not just by American lawyers, since from the one end US legal developments may have a profound impact on any international legal developments, and from the other end such developments should not lead to any unnecessary conflict with the established body of international space law either. In that sense, there is not only space for tourism, but also space for further discussion.

\section{$\underline{\text { Endnotes }}$}

1. See ECSL 33 - Special Edition, Report on the 2006 ECSL Practitioners' Forum, p. 2.

2. Commercial Space Launch Amendments Act of 2004, Public Law 108-492, $108^{\text {th }}$ Congress, 23 December 2004, 49 U.S.C.; 118 Stat. 3974.

3. Cf. Sec. 2(b), Commercial Space Launch Amendments Act, sub (14), referring to a period of eight years.

4. Cf. already Art. II, Treaty on Principles Governing the Activities of States in the Exploration and Use of Outer Space, including the Moon and Other Celestial Bodies (hereafter Outer Space Treaty), London/Moscow/ Washington, done 27 January 1967, 
entered into force 10 October 1967; 610 UNTS 205; TIAS 6347; 18 UST 2410; UKTS 1968 No. 10; Cmnd. 3198; ATS 1967 No. 24; 6 ILM 386 (1967).

5. Cf. e.g. Artt. III, IV, resp. Art. I, Outer Space Treaty.

6. Agreement on the Rescue of Astronauts, the Return of Astronauts and the Return of Objects Launched into Outer Space (hereafter Rescue Agreement), London/Moscow/ Washington, done 22 April 1968, entered into force 3 December 1968; 672 UNTS 119; TIAS 6599; 19 UST 7570; UKTS 1969 No. 56; Cmnd. 3786; ATS 1986 No. 8; 7 ILM 151 (1968).

\section{Artt. 1-4, Rescue Agreement.}

8. Convention on International Liability for Damage Caused by Space Objects (hereafter Liability Convention), London/Moscow/Washington, done 29 March 1972, entered into force 1 September 1972; 961 UNTS 187; TIAS 7762; 24 UST 2389; UKTS 1974 No. 16; Cmnd. 5068; ATS 1975 No. 5; 10 ILM 965 (1971).

9. See Artt. I(c), II, III, IV \& V, Liability Convention.

10. See Artt. II, III, Liability Convention.

11. See in particular Artt. I(b), (c), II(2), Convention on Registration of Objects Launched into Outer Space (hereafter Registration Convention), New York, done 14 January 1975, entered into force 15 September 1976; 1023 UNTS 15; TIAS 8480; 28 UST 695; UKTS 1978 No. 70; Cmnd. 6256; ATS 1986 No. 5; 14 ILM 43 (1975).
12. Based on Art. 17, Convention on International Civil Aviation (hereafter Chicago Convention), Chicago, done 7 December 1944, entered into force 4 April 1947; 15 UNTS 296; TIAS 1591; Cmd. 6614; UKTS 1953 No. 8; ATS 1957 No. 5; ICAO Doc. 7300, as this determines the nationality of aircraft based on their registration.

13. See Artt. II(1), IV(1), Registration Convention.

14. See ECSL 33 - Special Edition, Report on the 2006 ECSL Practitioners' Forum, p. 2.

15. See ECSL 33 - Special Edition, Report on the 2006 ECSL Practitioners' Forum, p. 3.

16. Most prominently, Article 31, Chicago Convention, provides that "Every aircraft engaged in international navigation shall be provided with a certificate of airworthiness issued or rendered valid by the State in which it is registered."

17. The JAA is based on a sui generis set of legal documents known as the JAA Arrangements, signed in Cyprus in 1990 by (at the time) ten states.

18. EASA was established by means of Regulation of the European Parliament and of the Council on common rules in the field of civil aviation and establishing a European Aviation Safety Agency, No. 1592/2002/EC, of 15 July 2002; OJ L 240/1 (2002).

19. See ECSL 33 - Special Edition, Report on the 2006 ECSL Practitioners' Forum, p. 3.

20. Sec. 2(b), Commercial Space Launch Amendments Act, sub (2). 
21. See Sec. 2(b), Commercial Space Launch Amendments Act, sub (17).

22. See ECSL 33 - Special Edition, Report on the 2006 ECSL Practitioners' Forum, p. 3.

23. The Warsaw system consists of a great number of partly overlapping international treaties, ranging from the 1929 Warsaw Convention (Convention for the Unification of Certain Rules Relating to International Transportation by Air, Warsaw, done 12 October 1929, entered into force 13 February 1933; 137 LNTS 11; USTS 876; UKTS 1933 No. 11; ATS 1963 No. 18) to the 1999 Montreal Convention (Convention for the Unification of Certain Rules for International Carriage by Air, Montreal, done 28 May 1999, entered into force 4 November 2003; ICAO Doc. 9740; 48 ZLW 326 (1999)).

24. See Sec. 2(c)(13), Commercial Space Launch Amendments Act.

25. See Sec. 70104, Commercial Space Transportation - Commercial Space Launch Activities, 49 U.S.C. 70101 (1994).

26. See Sec. 70112, Commercial Space Transportation - Commercial Space Launch Activities, 49 U.S.C. 70101 (1994).

27. See Art. VII, Outer Space Treaty; Art. I(c)(i), Liability Convention.

28. Outer Space Act, 18 July 1986, 1986 Chapter 38; National Space Legislation of the World, Vol. I (2001), at 293; Space Law - Basic Legal Documents, E.I; 36 Zeitschrift für Luftund Weltraumrecht (1987), at 12.
29. Secc. 1, 2(1), 3, Outer Space Act.

30. See Sec. 3(2)(b), resp. (3), Outer Space Act.

31. See Secc. 5(2)(f), 10(1), Outer Space Act.

32. Art. I(d), Liability Convention, includes the "launch vehicle" in the definition of "space object".

33. Law of the Russian Federation on Space Activities, No. 5663-1, 20 August 1993, effective 6 October 1993; National Space Legislation of the World, Vol. I (2001), at 101.

34. Art. 9(2), Law of the Russian Federation on Space Activities.

35. Art. 9(2), Law of the Russian Federation on Space Activities.

36. See Art. 30(1) \& (2), Law of the Russian Federation on Space Activities.

37. See Art. 25(1), Law of the Russian Federation on Space Activities. 